\title{
Glanzmann's thrombasthenia with mild von Willebrand's disease
}

\author{
R Nounou, D Spence
}

\begin{abstract}
A Saudi Arabian family is reported in which Glanzmann's thrombasthenia and von Willebrand's disease occurred simultaneously. The daughter presented with menorrhagia and gave a history of gastrointestinal bleeding and a strong family history of bleeding disorder. Full haematological investigations were performed on the propositus, parents, and siblings, including complete blood count, bleeding time, prothrombin time, partial thromboplastin time, factor VIII:C, von Willebrand factor, ristocetin cofactor, platelet aggregometry, platelet glycoprotein Ib and IIb/IIIa and platelet antigen PLT-1 (Coulter Clone). The propositus had Glanzmann's thrombasthenia, both parents had mild von Willebrand's disease and were carriers of Glanzmann's thrombasthenia. Three symptomatic brothers had both Glanzmann's thrombasthenia and von Willebrand's disease; two asymptomatic brothers had von Willebrand's disease only and one had completely normal results. Those family members with both diseases were more severely affected than those with just one disease.
\end{abstract}

In areas where consanguineous marriage is common, such as Saudi Arabia, multiple haemostatic abnormalities may occur, and investigation should not stop with the discovery of a single abnormality. The increased clinical severity of bleeding, including haemarthroses, in those patients having both congenital defects emphasises the importance of von Willebrand factor in glycoprotein Ib-mediated platelet adhesion.

(F Clin Pathol 1993;46:1134-1136)

Department of Pathology and Laboratory Medicine, King Faisal Specialist Hospital and Research Centre, PO Box 3354.

Riyadh 11211

Kingdom of Saudi

Arabia

R Nounou

Department of

Oncology

D Spence

Correspondence to:

Dr R Nounou

Accepted for publication

1 June 1993
Glanzmann's thrombasthenia is a rare congenital disorder of platelet function associated with a prolonged bleeding time, a normal platelet count, abnormal clot retraction and absent macroscopic platelet aggregation in response to adenosine 5'-diphosphate and other platelet agonists. ${ }^{12}$ This has been reported as relatively common in four populations-namely, French gypsies, Iraqi Jews, Indian people and Jordanian Arabs, ${ }^{3}$ probably as a consequence of consanguineous marriage increasing the incidence of autosomal recessive traits and thereby the likelihood of symptomatic homozygous subjects. Von
Willebrand's disease is the commonest and most heterogeneous congenital haemostatic disorder, with variable severity, and arising from quantitative or qualitative deficiency of the adhesive glycoprotein, von Willebrand factor.

\section{Case report and family history}

A 14 year old girl was referred with a history of severe menorrhagia at menarche, requiring multiple blood transfusions. She had also required transfusion for gastrointestinal bleeding when she was 8 years old. She gave a history of bleeding after dental extraction, not severe enough to require blood transfusion. When first seen she was iron deficient, but not bleeding, having received hormonal treatment at the referring hospital to suppress menstruation.

The patient's parents are first cousins and have six sons and one daughter (the propositus). The father, aged 43, had never experienced any bleeding abnormality but two of his brothers had died of severe bleeding after circumcision and another brother and a sister died of "oral bleeding" in childhood. The mother, aged 32, had heavy menstrual periods and experienced spontaneous bruises on the legs. When 15 years old, she had prolonged bleeding after tooth extraction, but no blood transfusion was required. She gave a history of prolonged postpartum haemorrhage when she delivered her daughter. The rest of her deliveries had been normal. She had no family history to suggest a familial bleeding diathesis. Three of the patient's brothers were symptomatic, all with spontaneous bruising, and two had haemarthroses of the knees and ankles. All had required blood transfusion during bleeding episodes, mainly epistaxis. The other three brothers were apparently normal.

\section{Methods}

Duplicate bleeding times were performed on separate occasions on all the family members using the Ivy method. Venous blood was obtained for duplicate haematological investigation, including complete count (CBC), prothrombin time (PT), and partial thromboplastin time (PTT) performed by standard methods. F VIII:C was assayed by a one stage technique using Universal Coagulation Reference Plasma (UCR) as a normal control (coefficient of variation (CV) $5 \cdot 2 \%$ ). Von Willebrand antigen (vWF:Ag) was measured 
Table 1 Haemostatic studies

\begin{tabular}{|c|c|c|c|c|c|c|c|c|c|c|c|}
\hline $\begin{array}{l}\text { Family } \\
\text { members }\end{array}$ & $\begin{array}{l}\text { Age } \\
\text { (years) }\end{array}$ & $\begin{array}{l}\text { Bleeding } \\
(2-10 \mathrm{~m})^{*}\end{array}$ & $\begin{array}{l}P T T \\
(26-38 s)^{*}\end{array}$ & $\begin{array}{l}\text { FVIII:C } \\
(0.5-2 \mu / \mathrm{ml})^{*}\end{array}$ & $\begin{array}{l}V W F: A g \\
(0 \cdot 5-1 \mu / m l)^{*}\end{array}$ & $\begin{array}{l}\operatorname{RiCoF} \\
(0 \cdot 5-1 \mu / \mathrm{ml})^{*}\end{array}$ & $\begin{array}{l}\text { Platelet } \\
\text { PLT-1 }\end{array}$ & $\begin{array}{l}\text { Platelet } \\
G p I b\end{array}$ & $\begin{array}{l}\text { Platelet } \\
\text { Gp IIb/IIIa } \\
\text { complex }\end{array}$ & $\begin{array}{l}\text { Clot } \\
\text { retraction }\end{array}$ & Diagnosis \\
\hline Propositus & 14 & $\begin{array}{l}>15 \\
>15 \\
>15\end{array}$ & $\begin{array}{l}32 \\
33 \\
30\end{array}$ & $\begin{array}{l}2 \cdot 10 \\
1.68 \\
1.63\end{array}$ & $\begin{array}{l}0.81 \\
0.75 \\
0.74\end{array}$ & $\begin{array}{l}1 \cdot 07 \\
1 \cdot 11 \\
1 \cdot 31\end{array}$ & $1 \%$ & $73 \%$ & Absent & Absent & $\begin{array}{l}\text { Type I Glanzmann's } \\
\text { thrombasthenia }\end{array}$ \\
\hline Father & 43 & $\begin{array}{l}4 \cdot 5 \\
6 \\
5 \cdot 5\end{array}$ & $\begin{array}{l}29 \\
28 \\
28\end{array}$ & $\begin{array}{l}0.93 \\
1.39 \\
1.34\end{array}$ & $\begin{array}{l}0.63 \\
0.73 \\
0.49\end{array}$ & $\begin{array}{l}0.44 \\
1.31 \\
0.62\end{array}$ & $101 \%$ & $118 \%$ & $39 \%$ & ND & $\begin{array}{l}\text { Von Willebrand's } \\
\text { disease } \\
\text { GT carrier }\end{array}$ \\
\hline Mother & 32 & $\begin{array}{c}14 \cdot 5 \\
6 \cdot 5 \\
7\end{array}$ & $\begin{array}{l}27 \\
31 \\
30\end{array}$ & $\begin{array}{l}0.70 \\
0.97 \\
1.01\end{array}$ & $\begin{array}{l}0.37 \\
0.40 \\
0 \cdot 40\end{array}$ & $\begin{array}{l}0.34 \\
1 \cdot 10 \\
0.53\end{array}$ & $99 \%$ & $89 \%$ & $47 \%$ & ND & $\begin{array}{l}\text { Von Willebrand's } \\
\text { disease } \\
\text { G T carrier }\end{array}$ \\
\hline Brother (1) & 13 & $\begin{array}{r}5 \\
>15\end{array}$ & $\begin{array}{l}37 \\
34\end{array}$ & $\begin{array}{l}0.74 \\
0.81\end{array}$ & $\begin{array}{l}0.25 \\
0.45\end{array}$ & $\begin{array}{l}0.75 \\
0 \cdot 23\end{array}$ & ND & ND & ND & ND & $\begin{array}{l}\text { Von Willebrand's } \\
\text { disease }\end{array}$ \\
\hline Brother (2) & 19 & $\begin{array}{l}>15 \\
>15\end{array}$ & $\begin{array}{l}35 \\
33\end{array}$ & $\begin{array}{l}1.50 \\
1.03\end{array}$ & $\begin{array}{l}0.49 \\
0.33\end{array}$ & $\begin{array}{l}1.18 \\
0.55\end{array}$ & $5 \%$ & $55 \%$ & $5 \%$ & Absent & $\begin{array}{l}\text { Type I Glanzmann's } \\
\text { thrombasthenia and } \\
\text { von Willebrand's } \\
\text { disease }\end{array}$ \\
\hline Brother (3) & 8 & $\begin{array}{r}>15 \\
14\end{array}$ & $\begin{array}{l}38 \\
34\end{array}$ & $\begin{array}{l}1 \cdot 46 \\
0 \cdot 71\end{array}$ & $\begin{array}{l}0.52 \\
0.43\end{array}$ & $\begin{array}{l}1 \cdot 07 \\
0.53\end{array}$ & $1 \%$ & $85 \%$ & Absent & Absent & $\begin{array}{l}\text { Type I Glanzmann's } \\
\text { thrombasthenia and } \\
\text { von Willebrand's } \\
\text { disease }\end{array}$ \\
\hline Brother (4) & 7 & $\begin{array}{l}8 \\
5\end{array}$ & $\begin{array}{l}32 \\
32\end{array}$ & $\begin{array}{l}1.81 \\
1.00\end{array}$ & $\begin{array}{l}0.75 \\
0.62\end{array}$ & $\begin{array}{l}1.46 \\
1.53\end{array}$ & ND & ND & ND & ND & Normal \\
\hline Brother (5) & 6 & $\begin{array}{r}11 \\
5 \cdot 5\end{array}$ & $\begin{array}{l}34 \\
33\end{array}$ & $\begin{array}{l}2 \cdot 28 \\
0.63\end{array}$ & $\begin{array}{l}0 \cdot 65 \\
0 \cdot 42\end{array}$ & $\begin{array}{l}1 \cdot 39 \\
0 \cdot 83\end{array}$ & ND & ND & ND & ND & $\begin{array}{l}\text { Von Willebrand's } \\
\text { disease }\end{array}$ \\
\hline Brother (6) & 3 & $\begin{array}{l}>15 \\
>15\end{array}$ & $\begin{array}{l}33 \\
30\end{array}$ & $\begin{array}{l}1.81 \\
1.81\end{array}$ & $\begin{array}{l}0.48 \\
0.36\end{array}$ & $\begin{array}{l}1 \cdot 05 \\
0 \cdot 71\end{array}$ & $8 \%$ & $24 \%$ & $11 \%$ & Reduced & $\begin{array}{l}\text { Type II Glanzmann's } \\
\text { thrombasthenia and } \\
\text { von Willebrand's } \\
\text { disease. Possibly } \\
\text { BSS heterozygote }\end{array}$ \\
\hline
\end{tabular}

by Laurell Rocket immunoelectrophoresis ${ }^{4}$ with UCR as a normal control (CV $7 \cdot 12 \%$ ), and an abnormal control from Biodata was also used. Ristocetin cofactor ( $\mathrm{RiCoF}$ ) was measured using lyophilised platelets, ${ }^{5}$ UCR being the normal control (CV 5.58\%), with the abnormal control being from Biodata. Platelet aggregometry of platelet rich plasma $(P R P)^{6}$ was performed using adenosine diphosphate (ADP) $1 \mu \mathrm{mol} / \mathrm{ml}$ and 2 $\mu \mathrm{mol} / \mathrm{ml}$, arachidonic acid $2.5 \mu \mathrm{g} / \mathrm{ml}$, collagen $2 \mathrm{mg} / \mathrm{ml}$ and $4 \mathrm{mg} / \mathrm{ml}$, and ristocetin $1 \mathrm{mg} / \mathrm{ml}$ and $1.5 \mathrm{mg} / \mathrm{ml}$. The platelet antigen PLT-1 (Coulter Clone) and glycoproteins $\mathrm{Ib}$ and IIb/IIIa complex were studied by flow cytometry (EPICS, Coulter).

\section{Results}

A summary of the haemostatic investigations is given in tables 1 and 2 . The propositus and brothers (2) and (3) have type I Glanzmann's thrombasthenia. Brother (6) seems to have a less severe form, type II, and in addition to have reduced glycoprotein $\mathrm{Ib}$, but blood platelet morphology was normal, and his platelets responded to ristocetin $(1.5 \mathrm{mg} / \mathrm{ml})$ in a manner similar to that of his siblings. No other family member had reduced glycoprotein Ib concentrations. Pending extended family studies, therefore, it cannot be excluded that the brother (6) is a BernardSoulier heterozygote in addition to the other inherited anomalies.

\section{Discussion}

The occurrence of both Glanzmann's thrombasthenia and von Willebrand's disease in a single family in which the parents are first cousins indicates that both parents carry the thrombasthenia gene. Four of their seven children have this disease, and in addition they both carry an abnormal von Willebrand's gene which is mild in expression and has been transmitted to some of their sons. Being carriers for both diseases has allowed the expression of either disease in some offspring or the simultaneous expression of both in others, reflecting the increased chance of coinheritance of rare disorders in populations where consanguineous marriage

Table 2 Platelet aggregation studies

\begin{tabular}{|c|c|c|c|c|c|c|c|}
\hline \multirow{2}{*}{$\begin{array}{l}\text { Aggregating agents } \\
\text { Dose }\end{array}$} & \multicolumn{2}{|c|}{$A D P(\mu \mathrm{mol} / \mathrm{ml})$} & \multicolumn{2}{|c|}{ Collagen $(\mu g / m l)$} & \multirow{2}{*}{$\frac{\text { Arachidonic acid }(\mathrm{mg} / \mathrm{ml})}{2.5}$} & \multicolumn{2}{|c|}{ Ristocetin $(\mathrm{mg} / \mathrm{ml})$} \\
\hline & 1 & 2 & 2 & 4 & & 1 & 1.5 \\
\hline $\begin{array}{l}\text { Propositus } \\
\text { Father } \\
\text { Mother }\end{array}$ & $\begin{array}{l}\text { Absent } \\
\text { Absent } \\
\text { Normal } \\
\text { Absent }\end{array}$ & $\begin{array}{l}\text { Absent } \\
\text { Absent } \\
\text { Normal } \\
\text { Primary } \\
\text { wave }\end{array}$ & $\begin{array}{l}\text { Absent } \\
\text { Absent } \\
\text { Normal } \\
\text { Normal }\end{array}$ & $\begin{array}{l}\text { Absent } \\
\text { Absent } \\
\text { Normal } \\
\text { Normal }\end{array}$ & $\begin{array}{l}\text { Absent } \\
\text { Absent } \\
\text { Normal } \\
\text { Normal }\end{array}$ & $\begin{array}{l}\text { Normal } \\
\text { Normal } \\
\text { Normal } \\
\text { Normal }\end{array}$ & $\begin{array}{l}\text { Normal } \\
\text { Normal } \\
\text { Normal } \\
\text { Normal }\end{array}$ \\
\hline & Absent & $\begin{array}{l}\text { Primary } \\
\text { wave }\end{array}$ & Normal & Normal & Normal & Normal & Normal \\
\hline $\begin{array}{l}\text { Brother (1) } \\
\text { Brother (2) } \\
\text { Brother (3) } \\
\text { Brother (4) } \\
\text { Brother (5) } \\
\text { Brother (6) }\end{array}$ & $\begin{array}{l}\text { Normal } \\
\text { Absent } \\
\text { Absent } \\
\text { Normal } \\
\text { Normal } \\
\text { Absent }\end{array}$ & $\begin{array}{l}\text { Normal } \\
\text { Absent } \\
\text { Absent } \\
\text { Normal } \\
\text { Normal } \\
\text { Absent }\end{array}$ & $\begin{array}{l}\text { Normal } \\
\text { Absent } \\
\text { Absent } \\
\text { Normal } \\
\text { Normal } \\
\text { Absent }\end{array}$ & $\begin{array}{l}\text { Normal } \\
\text { Absent } \\
\text { Absent } \\
\text { Normal } \\
\text { Normal } \\
\text { Absent }\end{array}$ & $\begin{array}{l}\text { Normal } \\
\text { Absent } \\
\text { Absent } \\
\text { Normal } \\
\text { Normal } \\
\text { Absent }\end{array}$ & $\begin{array}{l}\text { Normal } \\
\text { Present } \\
\text { Present }^{\star} \\
\text { Normal } \\
\text { Normal } \\
\text { Present }\end{array}$ & $\begin{array}{l}\text { Normal } \\
\text { Present }^{\star} \\
\text { Present }^{\star} \\
\text { Normal } \\
\text { Normal } \\
\text { Present }\end{array}$ \\
\hline
\end{tabular}

^Abnormal wave with the phenomenon of aggregation and disaggregation. 
is an accepted custom, as in Saudi Arabia. We have found no similar published description of such an occurrence.

Sporadic cases of Glanzmann's thrombasthenia have been reported from all over the world, but the disease seems to be relatively common in four populations-namely, French gypsies, Iraqi Jews, Indian people and Jordanian people. Therefore, although Glanzmann's thrombasthenia is typically a rare disorder, it can be almost as common as haemophilia and von Willebrand's disease in regions where consanguinity is common.

Many thrombasthenic women were initially diagnosed because of severe bleeding at menarche. ${ }^{2}$ The female propositus in this family had gastrointestinal bleeding when she was 8 years old, but she was not investigated fully until she had menorrhagia at menarche. The prevalence of haemarthrosis in this family is high, two of the brothers experiencing joint pain and swelling: both have Glanzmann's thrombasthenia type I and mild von Willebrand's disease. The third brother, affected by both diseases (with type II thrombasthenia), has not yet developed joint pathology at age 3 . The propositus was the only member who has thrombasthenia type I alone and did not give any history of joint swelling or pain. Therefore, we conclude that members expressing both diseases, thrombasthenia type I and mild von Willebrand's disease, are more severely affected than those who have one disease.

Von Willebrand factor is important as an adhesion molecule in the mechanism of platelet aggregation through its interaction with glycoprotein IIb/IIIa complex, independently of fibrinogen. ${ }^{7}$ It is also involved in progressive adhesion of platelets to subendothelium at high shear rate through its binding to glycoprotein IIb/IIIa-also independently of fibrinogen. ${ }^{8}$ The platelets of patients with severe Glanzmann's thrombasthenia may form a monolayer on subendothelial tissue in a perfusion system. ${ }^{9}$ Von Willebrand factor mediates initial platelet adhesion to subendothelium through interaction with glycoprotein Ib. ${ }^{10}$ In this kindred with Glanzmann's thrombasthenia the character and severity of the clinical haemostatic defect was apparently much more severe in those patients with severely reduced glycoprotein IIb/IIIa and von Willebrand's disease of mild degree. This confirms the critical role of von Willebrand factor in the mediation of platelet adhesion via the glycoprotein $\mathrm{Ib}$ mechanism.

Assays of platelet glycoproteins Ib and IIb/IIIa are considered useful not only in diagnosing Glanzmann's thrombasthenia and
Bernard-Soulier syndrome, but also in detecting the carrier states of these disorders. We found that PLT-1 antigen, a plateletmegakaryocyte antigen of undetermined molecular weight, was severely reduced in the patients with Glanzmann's thrombasthenia of both types, but was expressed in normal quantities in those with the carrier state. This observation implies a structural dependence on the presence of at least some glycoprotein IIb/IIIa.

Pending further investigations, it is premature to draw finer conclusions from the reduced glycoprotein $\mathrm{Ib}$ concentration in brother (6). Studies of the extended family will be required to confirm the possibility of the Bernard-Soulier gene also being present in this kindred.

There were no cases of double inheritance of the von Willebrand's gene, with consequent severe disease, in this family. The mother has not reported any miscarriages, but regularly has heavy menstrual periods, and it is possible that a severely affected fetus may not be viable.

Our experience with this family underlines the importance of careful studies in patients in Saudi Arabia, and their relatives, to exclude unusual combinations of congenital haemostatic disorders, which might require specially designed approaches to management.

We are grateful to Dr El-Hadi $M$ Abbas for referring the index case, to Mrs Fatmata Dawo for laboratory assistance, and to Ms Janet Lontoc and Ms MC Musngi for typing the manuscript.

1 Bennett JS, Shattil SJ. Disorders of hemostasis: Qualitative platelet disorders. In: Williams WJ, Beutler E, Erslev AJ, Lichtman MA, eds. Hematology. 4th Edn. New York: McGraw Hill Publishing Company, 1990: 1407-19.

2 George JN, Caen JP, Nurden AT. Glanzmann's thrombasthenia: the spectrum of clinical disease. Blood 1990; 75:1383-95.

3 Seligsohn U, Rososhansky S. A Glanzmann's thrombasthenia cluster among Iraqi Jews in Israel. Thromb Haemostas 1984;52:230-1.

4 Laurell CB. Quantitative estimation of protein by electrophoresis in agarose gel containing antibodies. Annal Biochem 1966;15:43.

5 Macfarlane DE, Stibbe DE, Kirby J, Zucker MB, Gran RA, Mcpherson J. A method for assaying Willebrand factor (ristocetin cofactor). Throm Diath Haem 1975; 34:306

6 O'Brien JR. Platelet aggregation II-Some results from a new method of study. F Clin Pathol 1962;15:452.

7 Weiss HJ, Hawiger J, Ruggeri ZM, Turitto VT, Thiagarajan $\mathrm{P}$, Hoffmann T. Fibrinogen-independent platelet adhesion and thrombus formation on subendothelium mediated by glycoprotein IIb-IIIa complex endothelium mediated by glycoprotein IIb-IIIa

8 Marco L, Girolami A, Zimmerman TS, Ruggeri ZM. von Willebrand factor interaction with the glycoprotein Willebrand factor interaction with the glyc
IIb/IIIa complex. $₹$ Clin Invest 1986;77:1272-7.

9 Weiss HJ, Turitto VT, Baumgartner HR. Effect of shear rate on platelet interaction with subendothelium in citrated and native blood. If Lab Clin Med 1978;92 750-64

10 Turitto VT, Weiss HJ, Baumgartner HR. Decreased platelet adhesion on vessel segments in von Willebrand's disease: A defect in initial platelet attachment. $₹ \mathrm{Lab}$ Clin Med 1983;102:551-64. 